\title{
Documentos
}

\section{Discurso de inauguración Galería de Ministros de Relaciones Exteriores de Chile. Viernes 23 de Junio de 2000.}

Domingo Santa María.

Señor Director del Instituto de Estudios Internacionales de la Universidad de Chile Don Rodrigo Díaz Albónico. Señor Embajador Don Carlos Martínez Sotomayor, Señoras y señores:

Muchas gracias, estimado director, por su amable invitación para intervenir en esta significativa ceremonia, mediante la cual el Instituto recuerda a los destacados Ministros de Relaciones Exteriores de Chile ya fallecidos.

Al leer la lista que acompaña a la invitación, uno queda asombrado por el número y la calidad de las personas que, a lo largo de casi 100 años, dirigieron la política exterior del país.

Brevemente, me referiré a uno de ellos, mi bisabuelo don Domingo Santa María González, quien desempeñara esas funciones durante la presidencia de don Aníbal Pinto, en plena Guerra del Pacífico.

Don Domingo nace en Santiago el 4 de agosto de 1824, en el seno de una familia de origen vascongado, avecindada en Chile en el siglo XVIII. En junio de 1846 contrae matrimonio con doña Emilia Márquez de la Plata y Guzmán. 
De profesión abogado, siendo aún muy joven -a los 23 años- ya se encuentra en el servicio público como Intendente de Colchagua.

Vuelto a Santiago, se ve involucrado en el fragor de la campaña electoral, que culminó con Manuel Montt en la Moneda y con él, exiliado en el Perú.

Al regreso de su destierro, se dedica a ejercer su profesión de abogado, con mucho éxito pero no por mucho tiempo. La vocación política es más fuerte. Así, en 1858, llega por primera vez a la Cámara como diputado por La Serena. Un año después sale nuevamente al exilio.

Durante la administración de don José Joaquín Pérez, se desempeña como Ministro de Hacienda y vuelve al parlamento, esta vez como Diputado por Valparaíso.

Y en el gobierno de don Aníbal Pinto, ya en plena Guerra del Pacífico, lo encontramos primero como Ministro de Relaciones Exteriores y luego como Ministro del Interior, cargo que abandona en junio de 1881 para concentrarse en la campaña electoral de ese año, en la cual es elegido Presidente de la República.

¿Cómo era su personalidad?

Leopoldo Castedo, en su «Resumen de la Historia de Chile de Encina» lo describe asî: «Santa María era, desde el punto de vista intelectual, el más brillante de los mandatarios chilenos; y como inteligencia, sólo cede ante la superioridad de don Manuel Montt. Había en él una rara exuberancia temperamental, una mente de euforia inagotable, que fulguró en el orador, en el escritor epistolar, en la tertulia política y en el hogar. Sencillo y modesto en sus hábitos, llegado a la presidencia siguió habitando la antigua casa de un piso y tres patios en la esquina sur-oriente de las calles Santo Domingo y San Antonio, sin alterar la patriarcal vida heredada».

Encina, por su parte, dice: «Por su vigoroso intelecto, su sensatez, su desdén por las anteojeras de los principios y las teorías políticas, su honradez militante, su vida conciencia de la responsabilidad del poder y su ardiente patriotismo, Santa María ocupa un alto puesto en la serie de los ocho presidentes portalianos. Paralelamente a la ardua tarea que le impuso la tercera etapa de la guerra, Santa María desarrolló una gestión administrativa y financiera sencillamente admirable».

Y él, ¿cómo se veía a si mismo?

El 8 de septiembre de 1885 le escribe a don Pablo Figueroa, quien preparaba un diccionario biográfico: «Yo sé que he cometido errores porque soy vehemente y apasionado, porque amo demasiado a mi patria y porque soy 
hombre de acción impetuosa en lo que estimo grande para mis conciudadanos y para esta preciosa tierra mía. He sufrido por esta tierra, han sufrido los míos; pero, que importa? Ya Chile es la potencia de Chile en América. Esto es lo que vale. Mis defectos no significan nada; mi pobreza tampoco; la pérdida de amigos queridos en las batallas de contradicciones y de odios me pesa ante sola palabra: hemos labrado la grandeza de Chile y podemos medirnos con los hombres que nos dieron patria casi de igual a igual porque hemos seguido su herencia imitándolos con la reverencia que nos merecen esos patriotas».

Al terminar su período presidencial, se ofreció a don Domingo una jubilación y una Legación. Rechazó ambas cosas y, al respecto, escribe a su amigo D. Víctor Manuel Prieto: «En relación con el viaje por esos mundos, aunque deseo emprenderlo, en la seguridad de que afianzaría mi salud, se me presen$\tan$ dificultades insuperables, una de las cuales es la salud de Emilia. Por otra parte, no puedo viajar de mi cuenta, desde que se ha menoscabado con la Presidencia mi fortuna privada y apenas tengo ahora con que sufragar los gastos de mi casa. Debo trabajar, una vez que la salud me lo permita y esto me apena y aflige. Ya estoy viejo». (tenía entonces 63 años).

Yen junio de 1889, le dice en carta a su amigo Emilio Crisólogo Varas: «Le escribo atribulado, pues frescas están todavía las lágrimas que aquí se derraman por Emilia, que falleció hace diez días, después de larga y penosa enfermedad. Ha muerto dejándonos imperecederos recuerdos y con tal resignación y energía que no es fácil encontrar en otra persona. Este valor moral lo da únicamente la virtud».

Y termina esa carta de verdadero desahogo con su amigo Emilio Crisólogo: «He tenido muchas penas que devorar, siendo la mayor de todas verme hoy viejo y achacoso y condenado a trabajar, por haber gastado parte de mi pequeña fortuna en la época en que goberné la República.

El 18 de Julio de 1889, a las nueve y tres cuarto de la mañana, murió don Domingo Santa María González, en Santiago, legando a los suyos su nombre y su ejemplo.

La tradición familiar nos dice que murió de pena, un mes después de haber enviudado.

Muchas gracias. 